\title{
The Generation of Mega Glacial Meltwater Floods and Their Geologic Impact \\ Paul A LaViolette*
}

The Starburst Foundation, 1176 Hedgewood Lane, Niskayuna, New York 12309, United States

\begin{abstract}
A mechanism is presented explaining how mega meltwater avalanches could be generated on the surface of a continental ice sheet. It is shown that during periods of excessive climatic warmth when the continental ice sheet surface was melting at an accelerated rate, self-amplifying, translating waves of glacial meltwater emerge as a distinct mechanism of meltwater transport. It is shown that such glacier waves would have been capable of attaining kinetic energies per kilometer of wave front equivalent to 12 million tons of TNT, to have achieved heights of 100 to 300 meters, and forward velocities as great as $900 \mathrm{~km} / \mathrm{hr}$. Glacier waves would not have been restricted to a particular locale, but could have been produced wherever continental ice sheets were present. Catastrophic floods produced by waves of such size and kinetic energy would be able to account for the character of the permafrost deposits found in Alaska and Siberia, flood features and numerous drumlin field formations seen in North America, and many of the lignite deposits found in Europe, Siberia, and North America. They also could account for how continental debris was transported thousands of kilometers into the mid North Atlantic to form Heinrich layers. It is proposed that such layers' form at times when a North Atlantic sea ice shelf borders the ice sheet and when climate warms abruptly producing accelerated meltwater discharge.
\end{abstract}

Keywords: Glacial meltwater floods; Glacier bursts; Permafrost deposits; Drumlins; Lignite deposits; Heinrich event; Supraglacial lakes

\section{Introduction}

Over a century ago Dana [1] in his Manual of Geology proposed that during periods of rapid glacial melting, the ice sheets may have released tremendous meltwater floods that reshaped the continental landscape. He stated (p. 553) that a flood "vast beyond conception" was the final event in the history of the North American ice sheet as indicated in the peculiar stratification of the flood deposits and in the dispersal of the stratified drift southward along the Mississippi Valley to the Gulf. He said that only under the rapid contribution of immense amounts of sand and gravel, and of water from such extensive a source could such deposits have been accumulated.

Some years later in 1893, Sir Howorth [2] voiced skepticism about Dana's idea. He wrote that if the climate was so cold as to accumulate enormous sheets of ice, he could not understand how the summer melting of this ice could be sufficiently rapid to produce such floods. He said that if floods were due to the melting of the ice, at the close of the glacial age, the change of climate involved must have been very sudden, or very rapid, much more sudden, and rapid than is consistent with any uniformitarian theory.

Howorth [2] makes a good point that meltwater would have been produced at an insufficient rate to result in catastrophic flooding. Even if the ice sheet surface were to have melted at a rate sufficient to raise sea level by $\sim 4 \mathrm{~cm}$ per day, the resulting subglacial meltwater outflow from the glacier's edge would not have been of very great depth. Take as an example the Laurentide Ice Sheet, which measured about 3,200 $\mathrm{km}$ from centre to edge along a north to south transect. During MWP $1 \mathrm{~A}$, it is estimated to have discharged $14,000 \mathrm{~km}^{3}$ of meltwater per year, or about $0.002 \mathrm{~km}^{3}$ per day from each kilometer of its perimeter. If meltwater were flowing continuously from its periphery at a speed of $10 \mathrm{~m} / \mathrm{s}$, this discharge would only have been about two meters deep. Greater flow speeds would result in even lesser depths. Certainly, a continuous meltwater discharge mechanism is not sufficient to account for the morphology of the flood deposits seen in regions bordering the ice sheet.
As one solution, it has been customary to suggest that meltwater had become impounded in proglacial lakes retained behind an ice dam and that once breached the resulting flood would have been forceful enough to sculpt the surrounding land features. Such a mechanism, for example, was first proposed by Bretz in a series of papers he wrote between 1923 and 1932 to explain the formation of the channelled topographic features in the Scabland region of eastern Washington. This flood, variously named the Spokane Flood or Missoula Flood, was attributed to the sudden emptying of proglacial Lake Missoula that once covered western Montana; Baker VR [3] for a review. Also, Kehew A et al. [4] have suggested a domino effect mechanism in which proglacial Lake Regina, which once resided in southern Saskatchewan, may have suddenly emptied, and created a catastrophic flood that moved south-eastward to trigger the sequential emptying of a series of interconnected proglacial lakes in Manitoba, North Dakota, and Minnesota (Lake Souris, Lake Hind, and Lake Agassiz).

But the above mechanisms, deal with relatively local, "small-scale" catastrophic floods, and have difficulty in explaining the great extent of the flood deposits found all over the world in regions lying more than a thousand kilometers from the ice sheet margin. They also have difficulty accounting for the presence of high altitude flood deposits, for example, the Alaskan upland silts which are found on ridges situated 250 to 650 meters above the valley floor [5]. Due to the fact that proglacial lakes lie at relatively low elevation, near the base of the

*Corresponding author: Paul A. LaViolette, The Starburst Foundation, 1176 Hedgewood Lane, Niskayuna, New York 12309, United States; E-mail: plaviolette@starburstfound.org

Received February 28, 2017; Accepted March 10, 2017; Published March 17 2017

Citation: LaViolette PA (2017) The Generation of Mega Glacial Meltwater Floods and Their Geologic Impact. Hydrol Current Res 8: 269. doi: 10.4172/2157 7587.1000269

Copyright: ( 2017 LaViolette PA. This is an open-access article distributed under the terms of the Creative Commons Attribution License, which permits unrestricted use, distribution, and reproduction in any medium, provided the original author and source are credited. 
ice sheet, floods from such lakes would have been unable to mount to such heights.

Shaw et al. [6,7] have proposed another mechanism in which water stored in subglacial reservoirs could have been catastrophically released from beneath the edge of the ice sheet to form sheet-like floods that were able to form the extensive drumlin fields observed in North America and Europe. Drumlins are oval or chevron-shaped hills seen to cover large areas of land that once lay at the border of the North American ice sheet. They measure about 60 to 100 feet in height, 1200 to 1800 feet in width and can range in length from less than half a mile to several miles. One such drumlin field in centralwestern New York is estimated to contain as many as 10,000 drumlins. Earlier theorists had suggested that drumlins have been created by glacial surges in which advancing glaciers smeared a mixture of clay, gravel, and boulders into streamlined mounds. Shaw, however, points out that drumlins were most likely produced by forceful discharges of glacial meltwater hundreds of feet deep and estimates that meltwater shaping the Livinstone Lake drumlin field in northern Saskatchewan was formed by at least $84,000 \mathrm{~km}^{3}$ of meltwater discharging at rates as high as 60 million $\mathrm{m}^{3} / \mathrm{s}$. He points out that a meltwater flood origin is more likely as drumlins have a shape similar to erosional forms produced by turbulent flows and resemble landforms normally ascribed to glaciofluvial action. He notes that the floodwaters forming these drumlin fields must have been at least as wide as the fields themselves, 20 to $150 \mathrm{~km}$, and must have been sufficiently deep to submerge the drumlin tops, in some cases a minimum of hundreds of feet deep.

The present paper investigates a novel mechanism by which mega floods, comparable to large scale tsunamis, could have been produced during the last ice age. It is proposed that during periods of major climatic warming, glacial meltwater was able to accumulate on an ice sheet's surface forming a multiplicity of supraglacial lakes. A dam failure of one such perched lake near the ice sheet summit then could trigger a consecutive domino-effect discharge of other perched lakes to creates a self-amplifying traveling meltwater wave, or water avalanche, of enormous height, mass, velocity, and kinetic energy, and consequently having great destructive force. This has been termed a "continental glacial meltwater wave," or "glacier wave" for short (Figure 1) [8]. It is proposed that this phenomenon occurred during the ice age partly because of the vast extent of the ice sheets, which existed at that time and partly because supraglacial lakes would have been present in

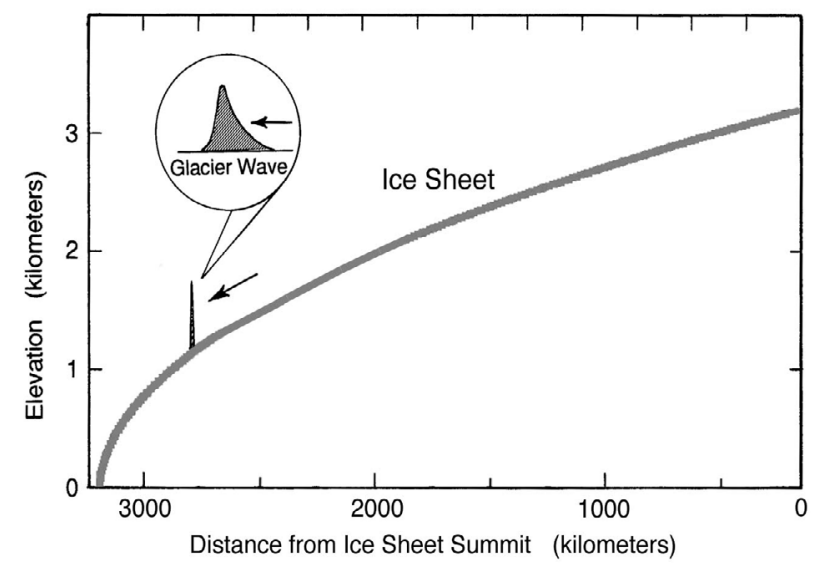

Figure 1: A glacier wave propagating down the surface of the Laurentide ice sheet. Ice sheet profile has been drawn with a vertical exaggeration of 2000:1. great numbers during the dramatic climatic warmings that periodically occurred at that time.

\section{Supraglacial Lakes Now and Then}

It is known that glaciers have the ability to store a considerable amount of meltwater on their surface in the form of perched ponds or lakes called supraglacial lakes. Also, meltwater can be stored on their surface in the form of runoff that moves laterally over its surface. Satellite observations show that a substantial number of supraglacial lakes are present on the Greenland Ice Sheet particularly during the summer melting season. Fitzpatrick et al. [9] studied several sectors of the Russel Glacier on the southwestern edge of the Greenland Ice Sheet extending from the ice sheet margin to $\sim 2000 \mathrm{~m}$ elevation. An area totalling $6500 \mathrm{~km}^{2}$ was studied over 11 melt seasons from 2002 to 2012 and found to contain an average of 200 supraglacial lakes. The lakes had an average area of $0.68 \mathrm{~km}^{2}$, but were observed to grow as large as $8 \mathrm{~km}^{2}$. Depending on the particular year of observation, total meltwater volume for these supraglacial lakes was found to range from $0.09 \mathrm{~km}^{3}$ to $0.25 \mathrm{~km}^{3}$ with the largest volume having occurred during the unusually warm summer of July 2012 . When averaged across the $6500 \mathrm{~km}^{2}$ study area, the 2012 meltwater volume would amount to an average depth of $3.8 \mathrm{~cm}$.

Fitzpatrick et al. [9] found that supraglacial lakes last an average of 10 days before rapidly draining due to the formation of hydraulic fractures, which form moulins that channel the water to the ice sheet bed. However, Koenig et al. [10] report that some lakes survive through the winter season as buried lakes located on average about 2 meters below the surface. They found that these could re-emerge as supraglacial lakes during the following melt season or in other cases can remain buried for multiple seasons before re-emerging.

A large amount of meltwater can also exist on the surface of the ice sheet in the form of supraglacial streams and rivers. Smith et al. [11] studied a 5,328 $\mathrm{km}^{2}$ area on the Greenland Ice Sheet and logged 5,928 $\mathrm{km}$ of large streams forming 523 supraglacial stream networks. They found that these rivers always terminated in moulins where the water was rapidly conveyed to the bottom of the ice sheet. In some cases, supraglacial streams were observed to pass through supraglacial lakes. They found that during the July 2012 summer, the total supraglacial storage, including supraglacial lakes, streams, and rivers, amounted to about $0.19 \mathrm{~km}^{3}$, equivalent to an average depth of $3.6 \pm 0.9 \mathrm{~cm}$, comparable to the findings of Fitzpatrick et al. [9].

Fitzpatrick et al. [9] found that in warmer years' supraglacial lakes were present at higher ice sheet elevations. In particular, Tedesco et al. [12] report that over the period of July 11-13, 2012 about $97 \%$ of the Greenland Ice Sheet underwent surface melting and that the melt extent exceeded $60 \%$ over a 10 -day period. In previous summer seasons, glacial lakes had covered about $40 \%$ of the ice sheet. Surface temperature during this 2012 melt period was observed to be $-5.5^{\circ}$ $\mathrm{C}$, the warmest in four decades. This may be compared with the period 2002-2009 when surface temperature averaged $-7.5^{\circ} \mathrm{C}$. Hence current observations show that there is a direct correlation between temperature at the ice sheet surface and the prevalence of supraglacial lakes and surface melting.

Studies of the ice record shows that, during the last ice age, periods of cold climate were abruptly interrupted by numerous warming events termed Dansgaard/ Oeschger (D/O) events. Also, the Earth's coral reef records show that during some of these warmings the ice sheets were melting far more rapidly than rates seen today in Greenland and 
Antarctica. One significant period was during the Alleröd/Bölling interstadial when the formerly glacial climate had warmed up to interglacial temperatures. Another period of interest is the abrupt warming event, which occurred at the end of the Younger Dryas (YD) that terminated the ice age. Borings of the Barbados coral reef, which have been dated by AMS ${ }^{14} \mathrm{C}$ and U-Th reveal that during both of these climatic warmings sea level was rising at exceedingly high rates due to the influx of glacial meltwater $[13,14]$. These two intervals of rapid meltwater influx were termed meltwater pulse 1a (MWP 1A) and MWP 1B. Liu et al. [14] date these as spanning 14.2 to $13.8 \mathrm{k}$ cal yrs $\mathrm{BP}$ and 11.5-11.1 k cal yrs BP respectively. During MWP 1A sea level is estimated to have risen at a rate of at least $4 \mathrm{~cm}$ per year $[14,15]$. Also, the data of Clark et al. [16] from coral reefs of Barbados and the Sunanda Shelf show an increase of $18 \mathrm{~m}$ over the period from 14.5$14.2 \mathrm{k}$ cal yrs BP, implying a rate of sea level rise of $6 \mathrm{~cm}$ per year, although their dates for MWP 1A fall about 300 years earlier. These indicate that sea level was rising about 12 to 18 times faster than the current average rate of $3.4 \mathrm{~mm}$ per year as reported by Nerem et al. [17]. Actually, the rates estimated for MWP 1A represent averages for these periods, the data being also consistent with sea level having risen even faster at specific times within these intervals. For MWP 1B event, Emiliani et al. [18] has reported a sea level rise of several meters per decade occurring around $11.5 \mathrm{k} \mathrm{cal} \mathrm{yr} \mathrm{BP}$ and has noted that this date coincides with Plato's flood date. Emiliani's [18] findings imply a sea level rise of about $20 \mathrm{~cm}$ per year, or about 60 times that of the current average. Although, Abdul et al. [19] report a lower rate of about $4 \mathrm{~cm}$ per year for this period, $11.45-11.1 \mathrm{k}$ cal yr BP. Also, other meltwater pulses have been found which predate MWP 1A. Yokoyama et al. [20] report finding an abrupt rise in sea level occurring around $19 \mathrm{k} \mathrm{cal} \mathrm{yrs}$ $\mathrm{BP}$ in the Bonaparte Gulf of Australia.

Given that the North American ice sheet at certain times during the last ice age was undergoing a rate of melting far greater than is seen today in Greenland, it is reasonable to conclude that supraglacial lakes were at those times far more prevalent than what was observed in Greenland during the 2012 melt season. Since ice melting would have primarily occurred at the ice sheet surface, it is reasonable to expect that there was a 12 to 60 -fold greater prevalence of supraglacial lakes during these periods of rapid sea level rise, as well as a comparable increase in the prevalence of surface meltwater runoff. Extrapolating from the average meltwater depths of 3.6-3.8 cm estimated for the Greenland Ice Sheet in 2012, this implies that the North American ice sheet during those times could have had an average equivalent distributed meltwater depth ranging from 0.5 to 2 meters. With this excessive output of meltwater, moulins that normally channel surface water to the ice sheet bedrock may have been filled to capacity and unable to convey meltwater to the bedrock surface as readily as those studied today. This would have resulted in an increased amount of water being impounded on the ice sheet surface. Also, one should consider that the summit of the North American ice sheet was then located around where the Hudson Bay is currently situated (lat. $53^{\circ} \mathrm{N}$ ). Hence, it would have lain $14^{\circ}$ further south from the latitude of the Russel Glacier region of Greenland $\left(67^{\circ} \mathrm{N}\right)$. Even though a large portion of the ice sheet surface would have been above 3000 meters' elevation, the North American ice sheet would have been receiving a greater amount of insolation facilitating its melting during interstadial periods.

With this supraglacial environment prevailing during episodes of extreme climatic warming, it is likely that on occasion one of the supraglacial lakes whose water was retained behind an ice jam could have melted sufficiently to cause a dam breach resulting in the sudden release of its water. Upon descending the ice sheet, such an outburst could trigger the successive emptying of supraglacial lakes resulting in a progressive growth of the flood wave according to the mechanism outlined in the next section. Meltwater outbursts from perched reservoirs are occasionally observed in modern times and have been variously termed glacier bursts or glacier floods [21,22]. Grimsvötn, Iceland is one such location that is prone to recurrent glacier bursts. Its floods issue from a large subglacial lake of area 35 to $40 \mathrm{~km}^{2}$ and depth of about 200 meters perched at a height of $\sim 1500$ meters above sea level. The lake is about three-fourths of the way to the summit of the Vatnajokull glacier at latitude $64.4^{\circ} \mathrm{N}$. Geothermal heat from an underlying active volcano causes ice to melt over a $300 \mathrm{~km}^{2}$ region and feed this perched lake. When the stored meltwater capacity becomes excessive, progressive failure of the lake's ice walls causes the catastrophic release of meltwater, during which about $7-8 \mathrm{~km}^{3}$ of glacial meltwater become discharged in the space of just a few days. Ward [22] notes that the exponential increase in discharge rate may be explained by a feedback process in which increased flood flow rate through the water transmitting channels progressively enlarges the channels which in turn progressively increases the flow rate.

Another example of a proglacial lake that periodically produces glacier bursts is the ice dammed Lake Merzbacher located on the Inylchek glacier in the Tien Shan Mountains of east Kyrgyzstan $\left(42^{\circ}\right.$ $\mathrm{N})$. The lake does not drain through most of the year, but when a hole finally melts through its dam, the lake drains within three days producing a discharge of up to $1000 \mathrm{~m}^{3} / \mathrm{s}$ that creates major flooding downstream $[23,24]$.

Although various mechanisms have been suggested for the cause of the sudden climatic warmings that occurred during the ice age, there is considerable evidence that these warmings had a solar cause. Several studies find there to be a link between solar variability and major variations of terrestrial ice age climate as in the production of $\mathrm{D} / \mathrm{O}$ events and other climatic oscillations [25-33].

Furthermore, there is evidence that the Sun was far more active during the last ice age than it is today. A study of solar flare tracks etched in lunar rock micrometeorite craters indicates that around $16 \mathrm{k}$ ago the average solar cosmic ray intensity was 50 times higher than at present, declining to 15 times higher by 12 kyrs BP, and eventually reaching its present activity level early in the Holocene [34]. Also, according to Zook [35] elevated radiocarbon levels found in the surfaces of lunar rocks indicate that between 17-12 k yrs BP the Moon was being exposed to a solar cosmic ray flux that averaged 30 times higher than its present flux [34]. He concluded that this unusually high solar activity, unlike anything we have seen in modern times, played a critical role in terminating the last ice age. Gold [36] studied glassy patches on the bottoms of lunar craters and found their surface to be covered by dust particles that had been heated to a molten state by an episode of intense heat. He concluded that, at some time in the past 30,000 years, the Sun must have produced a very large solar flare or nova-like outburst that caused its luminosity to increase 100-fold for a period of 10 to 100 seconds. Another theory is that this glazing was caused by one or more super-sized coronal mass ejections that had engulfed the Earth and Moon [8,37]. Of course, the Earth has far more protection from charged particles and UV radiation than does the Moon. But if the ozone layer were to be partially destroyed or the geomagnetic field were to significantly drop in intensity due to the occurrence of a main phase decrease during a super solar flare, this energetic radiation could make its way into the troposphere and contribute to the melting of the ice sheets.

On several occasions during the last ice age, the Earth received a substantial influx of extraterrestrial dust [38-40]. This dust was likely also present throughout the solar system on these occasions. 
Consequently, it is likely that substantial quantities were accreted by the Sun and to have aggravated the Sun into an extremely active state of flaring. Related to this, Hoyle et al. [41] demonstrated that the Sun's passage through an interstellar dust cloud could have contributed material at a sufficient rate to have increased its luminosity several percent. Dust shrouded stars having a mass similar to the Sun called $\mathrm{T}$ Tauri stars are observed to exhibit extremely high flaring activity, excessive luminosity, and infrared excesses. So, it is possible that, during the last ice age, the Sun could have been aggravated into a Tauri-like state which could explain the lunar rock findings of Zook et al. [35,36].

The Sun's luminosity is known to rise during periods of active flaring with the extra output being primarily in the UV and X-ray spectral regions. Bruns et al. [42] have noted that solar UV radiation increased by $25-30 \%$ during solar flares occurring in 1967 . Since UV wavelengths normally constitute about $10 \%$ of the Sun's luminosity, this implies a bolometric solar luminosity increase of $2.5-3 \%$ during flare events. Destruction of the ozone layer by the high levels of solar cosmic ray radiation occurring during the time of an extreme solar storm would have allowed this radiation to penetrate the stratosphere and exacerbate the heating of the troposphere particularly in high latitude regions. An active Sun, then, could explain episodes of abrupt climatic warmings and accompanying rapid ice sheet melting that occurred during the last ice age.

There is evidence that MWP 1B was produced by extreme solar events. For example, the GISP2 ice record registers an acidity spike at the end of the YD at a depth of 1678.3 meters (11,571 cal yrs BP), the largest such spike to occur during the entire YD [43]. It coincided with a one-year long cooling, registered as a -4 per mille change in oxygen isotope ratio, and was immediately followed by a 14-year long warming. This was followed one Hale solar cycle later $(11,549$ cal yrs BP) by an almost equally large acidity spike, which coincided with an abrupt climatic cooling followed by a decade-long warming that ended the YD and heralded the beginning of the Holocene. This terminal event also appears to coincide with a small ${ }^{10} \mathrm{Be}$ deposition rate peak. Also, Mörner [44] has observed that around 11,550 years $\mathrm{BP}$, the Earth's magnetic field intensity increased by more than fivefold. Further, he reports that between 14,500 and 11,550 cal yrs BP the intensity and declination of the Earth's magnetic field underwent major cyclic variations in step with the eleven-year sunspot cycle having an amplitude hundreds of times larger than modern geomagnetic solar cycles. So, the geomagnetic record supports the suggestion that the Sun was at that time perhaps more than an order of magnitude more active than it is today.

MWP 1A (14.2-13.8 k cal yrs BP) may also have been associated with a period of elevated solar activity. For example, studies of the varved record from the Cariaco Basin shows that a large spurt in ${ }^{14} \mathrm{C}$ production occurred around $14,050 \mathrm{cal}$ yrs BP. Also, Ising [45] has reported a large westerly magnetic declination swing occurring between 14.2 and $13.8 \mathrm{k} \mathrm{cal} \mathrm{yrs} \mathrm{BP}$ in southern Sweden.

\section{The Generation of a Glacier Meltwater Wave}

Consider now a period during the ice age when climate abruptly warmed to such an extent that the upper surface of the ice sheet was melting at a very fast rate causing supraglacial lakes, rivers, and streams to form in great abundance, over an order of magnitude greater than the prevalence seen today in Greenland. Suppose then that the ice sheet surface was covered with meltwater to such an extent that if dispersed evenly over the ice sheet surface it would have had an average depth of half a meter. This would have produced conditions favoring the generation of a glacier wave.
A glacier wave would initially have been seeded by a glacier burst similar to those we see taking place today at Grimsvötn and at other glacier locations. Suppose that an ice dam retaining a perched meltwater lake located near the center of the Laurentide Ice Sheet had failed resulting in the catastrophic release of $1 \mathrm{~km}^{3}$ of meltwater. Suppose that this produced a flood wave having a frontal length of 1 kilometers, a height of 10 meters, and a forward velocity of $10 \mathrm{~m} / \mathrm{s}$. A one-meter length of this wave would have a volume per meter of $\mathrm{v}=10^{6}$ $\mathrm{m}^{3}$, a mass of $10^{9} \mathrm{~kg}$, and a kinetic energy of $5 \times 10^{10}$ joules.

Whether this glacier wave would continue to grow in size as it travelled down the ice sheet slope, or whether it would become dissipated by the pools of water it encountered, would depend on whether its continued forward motion resulted in either a net energy gain or net energy loss for the wave. The kinetic energy required to accelerate the ambient meltwater medium that the wave encounters to its own forward velocity must necessarily come from the wave itself. Moreover, the wave, in turn, acquires its kinetic energy from its store of potential energy, which is gradually released as it travels forward down the glacier slope. If the energy demand on the wave to accelerate the encountered medium were to become so great that this rate of energy loss exceeded the wave's rate of energy gain from the kinetic energy acquired in the course of its descent down the glacier surface, the wave's velocity relative to the ambient medium would tend to diminish, and eventually the wave would dissipate. On the other hand, if the rate of kinetic energy acquisition were to exceed the rate of kinetic energy consumption, the net kinetic energy of the wave would increase and the wave would tend to accelerate.

Consider a 1 meter wide increment of a $10^{9} \mathrm{~kg}$ glacier burst wave such as that proposed above, having a height of 10 meters and forward velocity of $\mathrm{v}=10 \mathrm{~m} / \mathrm{s}$. As it travels forward over an ice sheet having water ponded at an average depth of 0.5 meters, it would encounter meltwater at the rate of

$$
\frac{d m}{d t}=1 \mathrm{~m} \times 0.5 \mathrm{~m} \times 10 \mathrm{~m} / \mathrm{s} \times 1000 \mathrm{~kg} / \mathrm{m}^{3}=5,000 \mathrm{~kg} / \mathrm{s}
$$

To bring this encountered water up to its own forward velocity, the wave would need to be supplying kinetic energy at the rate of

$$
\frac{d E_{\text {out }}}{d t}=1 / 2 \frac{d m}{d t} \mathrm{v}^{2}=1 / 2(5,000 \mathrm{~kg} / \mathrm{s}) \times(10 \mathrm{~m} / \mathrm{s})^{2}=2.5 \times 10^{5} \text { joules } / \mathrm{s}
$$

Let us assume that the ice sheet has a parabolic profile having a maximum elevation of 3200 meters and north-south distance extent of 3200 kilometers, as shown in Figure 1. Suppose that its elevation (y) varies as a function of its north-south distance $(\mathrm{x})$ as:

$$
\mathrm{y}=\frac{(3200-\mathrm{x})^{-0.5}}{17.5}
$$

Hence the gradient $\kappa$ of its surface contour on average would vary as: $\kappa=\frac{d y}{d x}=\frac{1}{35(3200-\mathrm{x})^{-0.5}}$

Consequently, as this one-meter wave increment advanced down the glacier slope, it would drop in altitude at the rate of:

$$
\frac{d h}{d t}=\kappa \mathrm{v}=\frac{0.29}{(3200-\mathrm{x})^{-0.5}} \mathrm{~m} / \mathrm{s}
$$

and would be converting potential energy into kinetic energy at the rate of :

$$
\frac{d E_{\text {in }}}{d t}=\varepsilon \mathrm{mg} \frac{d h}{d t}=0.9 \times 10^{9} \mathrm{~kg} \times 9.8 \mathrm{~m} / \mathrm{s}^{2} \times \frac{0.29}{(3200-\mathrm{x})^{-0.5}} \mathrm{~m} / \mathrm{s}=\frac{2.52 \times 10^{9}}{(3200-\mathrm{x})^{-0.5}} \text { joules } / \mathrm{s}
$$

where $\varepsilon$ is the efficiency with which the advancing wave transfers energy to the ambient ponded meltwater to accelerate it to the wave's forward velocity. Here we take $\varepsilon$ to be $90 \%$, which supposes that the majority 
of the consumed kinetic energy goes into accelerating this water in the forward direction, the remainder being, converted into turbulence and frictional losses. Parameter $g$ is the gravitational constant $9.81 \mathrm{~m} / \mathrm{s}^{2}$.

In this particular case for $\mathrm{x}=100$, we find that $\frac{d E_{i n}}{d t}>>\frac{d E_{\text {out }}}{d t}$. Hence, the wave will accelerate and its store of forward kinetic energy will increase. The wave is predicted to accelerate even if the conversion efficiency is assumed to be almost an order of magnitude smaller.

As the glacier wave descends the slope of the ice sheet, it will grow in size and mass, and hence be able to release potential energy at a greater rate as it advances. If the wave were to sweep up all of the meltwater encountered in its path in the course of its $3200-\mathrm{km}$ journey, and if this meltwater were formerly stored on the surface of the ice sheet at an average depth of 0.5 meters, then by the time the glacier wave had reached the edge of the ice sheet, every meter along the wavefront would hold a volume of $1.6 \times 10^{-3} \mathrm{~km}^{3}$; i.e., $1 \mathrm{~m} \times 0.5 \mathrm{~m} \times 3.2$ $\times 10^{6} \mathrm{~m}$. This might express in the form of a wave having a height of $\sim$ 100 meters and overall length of $\sim 16$ kilometers in its travel direction. A one meter wide increment of this wave along its front would have accumulated a mass of $\mathrm{M}=1.6 \times 10^{9} \mathrm{~kg}$ by the time it reached the bottom of the ice sheet.

If we ignore drag due to air friction and air turbulence, a glacier wave originating from the ice sheet summit $(\mathrm{h}=3200 \mathrm{~m})$ would theoretically attain a velocity of $\mathrm{v} \sim 250 \mathrm{~m} / \mathrm{s}(\sim 900 \mathrm{~km} / \mathrm{hr})$ by the time it reached the edge of the ice sheet, where

$$
\mathrm{v}=(2 \mathrm{gh})^{1 / 2}
$$

Every meter along the front of the wave then would be accelerating forward with a force of $4.5 \times 10^{8}$ Newtons; i.e., $\mathrm{F}=\mathrm{mg} \mathrm{\kappa}$.

A wave traveling at $250 \mathrm{~m} / \mathrm{s}$ (Mach 0.73), and having a height $\mathrm{D}=100$ meters, will have a Reynold's number $\mathrm{Re}=\mathrm{vD} / \mathrm{v} \sim 2 \times 10^{9}$ indicating turbulent flow, where $v=1.17 \times 10^{-5} \mathrm{~m}^{2} / \mathrm{s}$ is the air kinematic viscosity at $0^{\circ} \mathrm{C}$. The equation for the air drag on the wave is given as:

$$
\mathrm{F}_{\mathrm{d}}=1 / 2 \rho \mathrm{v}^{2} \mathrm{C}_{\mathrm{D}} \mathrm{A}
$$

where $\rho=1.29 \mathrm{~kg} / \mathrm{m}^{3}$ is the density of air at $0^{\circ} \mathrm{C}, \mathrm{v}$ is the wave velocity, $\mathrm{C}_{\mathrm{D}}$ is the drag coefficient, and $\mathrm{A}$ is the area of the wave front for an incremental section of 1 meter along the front of the wave transverse to the direction of its motion. We assume that the wave has a drag coefficient of 0.016 , similar to that for wind stress acting on the ocean [46]. A 100-meter-high wave that rises to its maximum height over 8 kilometers will present a surface area of $8,000 \mathrm{~m}^{2}$ per meter of wave front. Hence, Equation (8) predicts an air drag force of 5.2 million Newtons, which is about $1 \%$ of the gravitational force acting to accelerate the wave forward. So, air drag will not substantially reduce the wave's velocity. Earlier in its journey when the wave's velocity is lower, this retarding force would be even lower.

Upon reaching the edge of the ice sheet, traveling at the speed of $250 \mathrm{~m} / \mathrm{s}$, the wave would be transporting meltwater at the rate of 400 $\mathrm{km}^{3} / \mathrm{s}$ per kilometer of wave front. For a wave of mass $\mathrm{m}=1.6 \times 10^{12} \mathrm{~kg}$ per kilometer frontage and $\mathrm{v}=250 \mathrm{~m} / \mathrm{s}$, each kilometer length of the wave front would be delivering a sum total kinetic energy of about 5 $\times 10^{16}$ joules, equivalent to about 12 million tons of TNT, or about 800 Hiroshima A-bombs. Compared with the initial glacier burst that seeded the glacier wave near the crest of the ice sheet, upon reaching the edge of the ice sheet, this glacier wave, now greatly grown in size, would have a kinetic energy per meter of wave front that was 1,000-fold greater.
The example discussed here, of course, is only a rough estimate made for the purpose of illustration. However, a more precise analysis would still render essentially the same results. Namely, in a nonequilibrium, low-friction regime such as would exist on the sloping surface of a rapidly melting continental glacier, if a meltwater seed wave of sufficient size were generated somewhere on the ice sheet surface as a result of an ice dam breech, this wave would spontaneously grow in size through a "domino effect." Beyond a critical threshold of wave size, a growing glacier wave would become the dominant mechanism of meltwater transport from the ice sheet since a glacier wave would be capable of dissipating potential energy at a greater rate as compared with homogeneous meltwater flow. Therefore, thermodynamic considerations support the theory that such waves would have existed during the ice age period.

Glacier wave growth would take place not only along the direction of travel, but along the length of the wave front as well. A dam failure beginning as a localized event near the summit of the ice sheet could fan out to form an extended wave front, measuring hundreds, perhaps even a thousand kilometers in length, by the time it had reached the ice sheet border. Upon encountering proglacial lakes at the foot of the ice sheet, a glacier wave of the magnitude estimated above would have enough force to jettison the entire lake over its retaining moraines or ice dam. For example, Proglacial Lake Missoula in northern Montana is estimated to have contained about $2000 \mathrm{~km}^{3}$ of meltwater [47]. By comparison, a $100 \mathrm{~km}$ long section of a glacier wave of the size proposed above coming from the Cordilleran Ice Sheet would have contained about $160 \mathrm{~km}^{3}$ of meltwater (along with chunks of unmelted ice). If a wave of this size were to accelerate the entire lake to its own bulk velocity, the wave would suffer a 3.7 -fold drop in velocity to about 70 meters per second. Thus, the flood features of the Channeled Scabland could just as well be attributed to the action of a major glacier wave or a series of such waves causing rapid discharge of Lake Missoula. Alternatively, a glacier wave by itself may have been sufficient to cause such features.

Upon reaching the edge of the ice sheet, a glacier wave consisting of an avalanche of water, unmelted ice chunks, and other debris traveling forward at a speed of several hundred meters per second, would have reduced its forward velocity, shortened its length, and grown in height much like a tsunami does when it reaches land. Perhaps reaching a height of 300 meters and having a frontal length of a thousand kilometers, such a wave could have traversed thousands of kilometers over a continental land mass before becoming dissipated. Upon entering the ocean, such a glacier wave would have caused a considerable volume displacement of the water mass, resulting in a mega tsunami that could have crossed thousands of kilometers of ocean and still had sufficient energy to produce considerable erosion on remote shores.

To demonstrate that avalanches could produce waves of the proposed height, one may cite as an example the Lituya Bay, Alaska mega tsunami $[48,49]$. This occurred on July 9, 1958 as a result of a rockslide triggered by a 7.7 magnitude earthquake. Approximately 40 million $\mathrm{m}^{3}$ of rock debris fell from an elevation of 914 meters into the head of the bay displacing its water. The mega tsunami so produced ran up to a height of 524 meters on the opposite side of the bay stripping its trees and eroding the soil down to its bedrock. Some estimate that the wave achieved an average velocity of 240 miles per hour and a height of 30 to 60 meters as it traveled out into the bay. If we assume that the avalanche fell from an average height of 700 meters, equation (6) given above would predict that, by the time it reached sea level, it would have been moving forward at 260 miles per hour which is 
close to the value given above for the wave velocity in the bay. By this example from Alaska, the suggestion that a wave of far greater kinetic energy launched from a fourfold greater height on the ice sheet surface would have achieved a height of 300 meters and forward velocity of 550 miles per hour does not sound that farfetched. The proposed glacier wave could have had a run-up of almost 1500 meters, able to surmount mountains of moderate height.

Looking at the Barbados coral record and considering other periods during the deglaciation period, other than the MWP 1A and MWP 1B spurts, it is apparent that the ice sheets were still melting far faster than today. For example, between 13-14 k cal yrs BP sea level was rising at the rate of $1 \mathrm{~cm}$ per year, or over 3 times faster than the current sea level rise. If we assume that during this period the ice sheet surface had an average meltwater depth over three times more than was observed in 2012 for the Greenland Ice Sheet, this would then amount to $10 \mathrm{~cm}$ instead of the $50 \mathrm{~cm}$ that we assumed in the calculations above. At this reduced average meltwater depth, a glacier wave would still have been able to grow in size as it progressed down the ice sheet. Only, its kinetic energy would have been about 5 times less than what was estimated above for an average meltwater depth of $50 \mathrm{~cm}$.

Glacier waves could also have formed during the cold Younger Dryas period. The "quarter bag" $\delta^{18} \mathrm{O}$ profile obtained from the GRIP ice core record (Figure 2) shows that as many as 20 brief warming episodes occurred during the Younger Dryas in which temperatures approached Holocene temperatures. Meltwater pulses produced during these warm periods each lasting from several years to a few decades would have passed unnoticed in the coral reef sea level record due to not having sufficient resolution. Once the warming event terminated, snow would have accumulated causing sea level to fall once again. During one such climatic warming which occurred in the early Younger Dryas (see arrow in Figure 2), temperatures rose to their maximum warmth within the span of a few years. This event occurred immediately after a dramatic rise in atmospheric ${ }^{14} \mathrm{C}$ concentration that dates around 12,837 years $\mathrm{BP}$ in the Cariaco Basin radiocarbon record. It was associated with spikes in ${ }^{10} \mathrm{Be}$ concentration, nitrate ion concentration, and ice acidity as seen in the GISP 2 Greenland ice core record. All of these suggest that the Earth at that time had been impacted by a super solar proton event (SPE) [43].

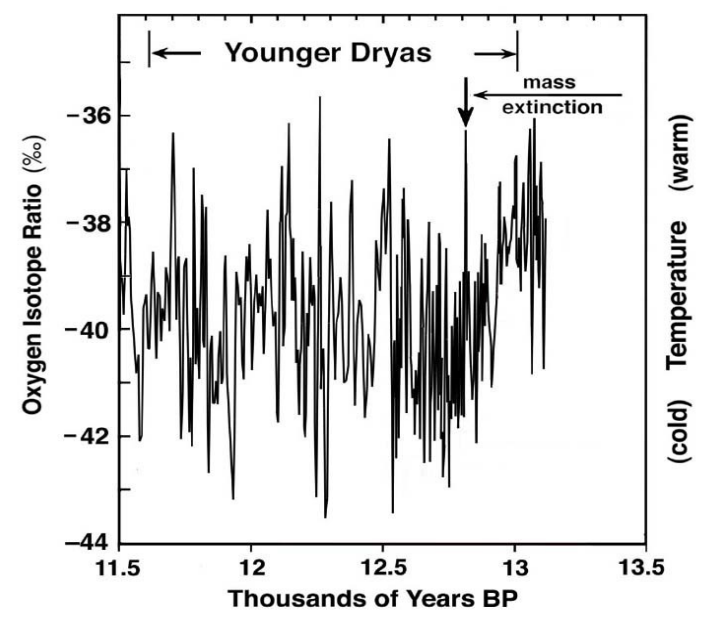

Figure 2: Oxygen isotope profile for the GRIP Summit, Greenland ice core spanning the Younger Dryas (data courtesy of S. Johnsen). The profile's chronology has been adjusted to correspond to the Cariaco Basin varved record.
In summary, it is suggested here that many of the loam-like drift deposits observed in many areas of the world that were once periglacial regions during the Wisconsin Ice Age are flood deposits produced by a series of such glacier waves issuing from the continental ice sheets. If a major climatic amelioration simultaneously affected all of the Earth's ice sheets, these glacier waves from different ice sheet locations would likely have been released all at about the same time.

\section{Explaining the Permafrost Silt Deposits of the Arctic Regions}

Almost all areas of Alaska that lie below an altitude of 300-450 meters are covered with a loamy blanket of perennially frozen silt that ranges in thickness from a few millimeters to over 60 meters [50]. For at least 100 years there has been a controversy as to the origin of this material, referred to locally as "muck." Explanations in the geological literature have mostly included gradually acting processes, such as fluvial, lacustrine, marine, and eolian deposition mechanisms and weathering.

Several Alaskan silt formations have been distinguished, dating as far back as the Illinoian glaciation. Of these formations, the Goldstream Formation is of particular interest. This is one of the most widespread formations in central Alaska and is believed to date from the latter portion of the Wisconsin Ice Age [51,52]. It is a valleybottom accumulation which is present in almost all creek and small river valleys in central Alaska. The Goldstream Formation is regarded as the greatest depository of Pleistocene vertebrate remains in Alaska if not in North America [51]. Most of these fossils are found in valley bottoms and the greatest concentrations occur where small tributaries join large creeks [50].

Péwé [5] reports that in the Fairbanks area (as one example) the silt ranges from 0.5 to 25 meters in thickness on the tops of low hills located 15-45 meters above the valley floor and thins out to a thickness of about a meter on ridges situated 250-600 meters above the valley floor. Clearly, normal fluvial action, such as that proposed by some theoreticians to explain the valley bottom deposits, has considerable difficulty accounting for deposits perched at such altitudes. Again, many theories have been put forth to account for the origin of the upland silt, ranging from an estuarian inundation of Central Alaska to high velocity winds as the transporting agent. Péwé [5] reviews a number of these theories and concludes that an eolian mechanism best accounts for the upland silt. However, if wind were the transporting agent, then one might ask why should such "wind-blown" material often be found to overlie auriferous gravel deposits. For example, Péwé [5] reports that on top of Gold Hill at an altitude of about 220 meters ( 80 meters above the flood plain) a bore hole revealed the presence of 50 meters of dry upland silt overlying auriferous gravels. The eolian hypothesis must attribute this to chance superposition, the deposition of wind-blown loess over a pre-existing auriferous gravel substrate. The glacier wave flood hypothesis, though, is able to not only account for the origin of the silt and the gravel, but also for their stratigraphic placement relative to one another.

Besides the unique stratigraphic placement of the placer gold, these upland silt deposits also bear a resemblance to the valley bottom deposits in that the silt is often found to overlie the remains of extinct megafauna; e.g., see Taber S [53] or Péwé TL [5]. Péwé [5,50,51] attempts to account for the upland silts in terms of eolian transport and for the valley bottom deposits (e.g., the Goldstream Formation) in terms of fluvial action. But such completely different transport mechanisms fail to explain why these high and low elevation deposits 
are so strikingly similar. A glacier meltwater wave, on the other hand, would be able to account for the formation of both the valley bottom deposits and the upland silts, and explain their similarity.

Of the various other proposals accounting for the origin of the Alaskan upland silts it is interesting to consider the lacustrine hypothesis as put forth by Eakin [54,55]. Eakin [55] states that the "mechanical analysis of the silt seems to indicate more strongly an aqueous rather than an eolian origin." He cites several geomorphic features to support his argument. For example, he notes that the presence of plains standing at different elevations connected by steep scarps running for several miles in length could have been produced only by aqueous erosion.

He notes that some agency must have eliminated the old base-level of erosion and established a new base-level at a much greater elevation, nearly 300 meters above the present level of the Yukon at Ruby. He proposed that this base-level change involved extensive inundation of the old land surface, a fact indicated by the character, structure, distribution, and topographic expression of the unconsolidated deposits and of the bedrock beneath them. He suggested that a 150,000$250,000 \mathrm{~km}^{2}$ region in central Alaska had temporarily impounded glacial meltwater to a height of 380 meters, drainage to the sea being blocked by an ice dam.

Péwé [5] offers several convincing criticisms of Eakin's hypothesis, such as the lack of evidence for the required drainage barrier, the lack of lacustrine varves, clay, or aquatic life in the silt deposits, and the finding that the silts do not have a definite upper limit in their altitude. However, while Péwés criticisms correctly rule out the lacustrine scenario, they leave untouched Eakin's conclusions that the silts are of aquatic origin. In fact, many of Eakin's suggestions could be rescued from these criticisms if the glacial meltwater inundation of central Alaska was short-lived, involving a translating wave of water. It is interesting to note that the divide between the Laurentide and Cordilleran ice sheets created a natural water course which emptied northward onto the central Alaskan plains. This geographic feature could have served to channel glacial meltwater to this region whether the meltwater originated from the ice sheet surface itself in the form of a glacier wave, or whether it involved (more conventionally) the sudden release of water impounded behind an ice jam such as may have occurred in the ice sheet divide.

The same depositional agent forming the Alaskan muck appears to also have been at work in Northern Siberia forming the so called "mammoth horizon" or "tundra horizon." Péwé et al. [52] call attention to the striking resemblance between the perennially frozen silt deposits in Central Alaska and those found in central Yakutia. They note that both areas consist of unglaciated rolling lowlands and river terraces surrounded by high mountains that were extensively glaciated in Pleistocene times. Thus, they suggest that a similar depositional history for these geographically widely separated regions would not be surprising. It is worth noting that if glacier waves were the depositional agents in these two subarctic regions and were similarly generated from bordering glaciers, one would expect to find a similarity in the deposits found in these two regions, in agreement with the observation.

It is here proposed instead that these flooding episodes manifested as a sequence of large scale, high kinetic energy meltwater waves created during intervals of major climatic warmings. Most regions of Northern Siberia and Alaska were within $2000 \mathrm{~km}$ of the edge of the Laurentide Ice Sheet (Siberia by a polar route). In addition, Northern Siberia also had alpine-type glaciers. Thus, in the event of a sudden climatic amelioration, it is easy to see how flooding could take place on a widespread scale throughout these arctic regions. It could also explain flood deposits found in North America in regions that lay south of the southern edge of the ice sheet as well as features found in regions that once lay south of the European ice sheet.

High kinetic energy, glacier waves could also simultaneously account for many of the puzzling features of the megafaunal deposits found in these regions. The meltwater not only would have drowned, fragmented, and buried the animals without warning, but it also would have tended to preserve their remains from decay. The icy contents of a glacier wave would have been close to $0^{\circ} \mathrm{C}$ and would probably have been composed of a slushy mixture of cold meltwater, ice chunks, and detritus which together would have helped to refrigerate the carcasses. With the onset of the Holocene, climate changed from boreal to arctic as winter snow was deposited over these near freezing deposits. The change of albedo would have locked this region into a permanently frozen state.

\section{The Formation of lignite deposits}

Glacier waves could also account for the accumulation of large quantities of carbonized peat found buried in valleys in various parts of Europe, Canada, and northern United States. As one example, many such lignite deposits are found in both central Peloponnesus and northern Greece. The deposit found in the Peloponnesian town of Megalopolis is believed to be of Pleistocene age. It is situated in a basin that is elongated in a north-south direction and encircled by mountains that rise to elevations of 1250 to 1500 meters. The basin floor itself lies about 400 meters above sea level and at its centre holds an extensive deposit of carbonized peat measuring some 30 square kilometers and in places reaches a depth of as much as 70 meters. Upon close examination, this material is found to consist of a conglomeration of wood pulp, tiny bits of organic matter, and wood chips ranging in size from a few millimetres to several centimetres, all turned dark brown in colour. The condition of the material gives the impression that the wood and vegetable matter had been violently shredded by flood waters and interred while still in a fresh state. Moreover, the stratified appearance of the deposit, with its interleaved horizontal zones of clay and gravel, indicates that this material had been deposited catastrophically, as if having precipitated from the transient presence of flood-waters.

We are presented with the image of a forceful glacier wave proceeding southward from the edge of the European ice sheet advancing over the land surface, scouring it clean of its thick vegetation, and still possessing sufficient kinetic energy to surmount the high mountain peaks that ring the Megalopolis valley. As the wave washed over this basin, its waters would have unburdened themselves of their load of clay and pulverized organic matter to form the deposits that today are mined for their fuel value. Begossi et al. [56] have similarly proposed a catastrophic flood origin for the Rio Bonito Formation coal deposits found in the Paraná Basin of Brazil. They have suggested that the deposits were laid down by a glacial outburst flood issuing from a melting mountain glacier.

At Megalopolis, lignite deposits are found in some places to overlie the bones of mammoths [57,58]. The discovery of such bones in antiquity may have inspired the ancient Greeks to call this area the "Battleground of the Giants." Lignite deposits containing the remains of Pleistocene mammals are also found in the northeastern Carpathians of central Europe [59]. Also, large lignite beds located near Lake Zurich have been found to contain the bones of mammoth, hippopotamus, rhinoceros, bear, and other mammals [60]. In Northern Siberia lignite, 
Citation: LaViolette PA (2017) The Generation of Mega Glacial Meltwater Floods and Their Geologic Impact. Hydrol Current Res 8: 269. doi: 10.4172/2157-7587.1000269

has been found embedded together with mammoth bones [61].

In the case of the Megalopolis lignite deposit, common assumption is that these deposits were formed gradually over a period of about a million years and that prevailing bog conditions preserved fallen trees from decay. The brown color of the lignite is typically attributed to sulphurous fumes that had acted on the deposits while they were interred. However, this gradualistic theory fails to account for the character of the wood which has been shredded presumably by the action of violent forces. Also, it doesn't explain the stratified nature of the deposits which present the hallmarks of catastrophic deposition by the action of flood waters. The proposal that glacier waves are often generated during periods of high solar activity could explain the dark color of the lignite. A super solar proton event intense enough to eliminate the protection of the geomagnetic field would have allowed solar cosmic ray particles and their shower of secondary electrons to pass to the Earth's surface where they could have carbonized trees while still standing. The glacier wave arriving shortly afterward would have shredded and transported this material leaving it to settle out in valley areas.

\section{The origin of Heinrich events}

Heinrich [62] reported discovering that North Atlantic sediments contain layers composed primarily of rock grains of continental origin with unusually low concentrations of foraminifera plankton. Studies of these so called "Heinrich layers," or "Heinrich events" indicate that continental bedrock debris was somehow transported for distances of up to 3000 kilometers before being deposited at these mid ocean locations. These layers appear only in ice age sediments and recur at intervals of 5000 to 10,000 years. They occur at the endings of ice ages as well as within glacial periods where they herald the onset of $\mathrm{D} / \mathrm{O}$ events. These layers are found to be most prominent at the mouths of the Gulf of St. Lawrence, the Hudson Bay, and the Denmark Strait as well as a few other locations, which are generally recognized as evidence that this material was somehow being transported by outflow from the continental ice sheet. A 90,000-year record of Heinrich event debris layers found in core V23-81 is shown in Figure 3. Also, Figure 4 shows the foraminifera climate profile for core V23-81 published by Broecker et al. [63] with the positions of Heinrich events $\mathrm{H} 1$ and $\mathrm{H} 0$ in this core superimposed for comparison.

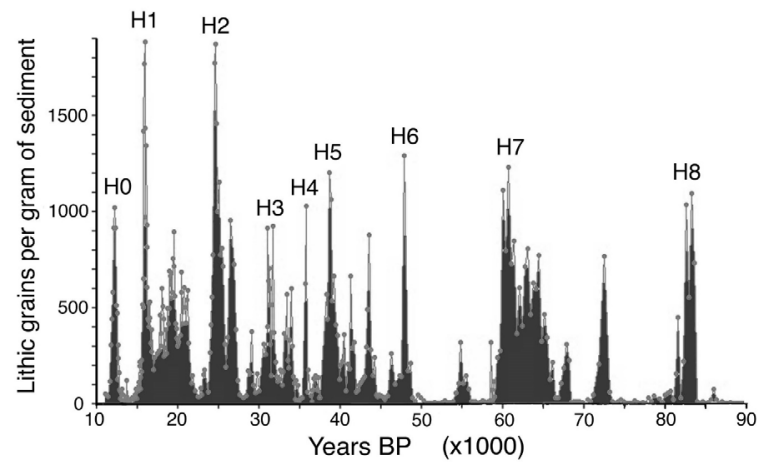

Figure 3: Heinrich events over the last 90,000 years, as seen in North Atlantic sediment core V23-81 (Data courtesy of Bond G [69,71]). The timescale adopted for this core is given in text box 1 .

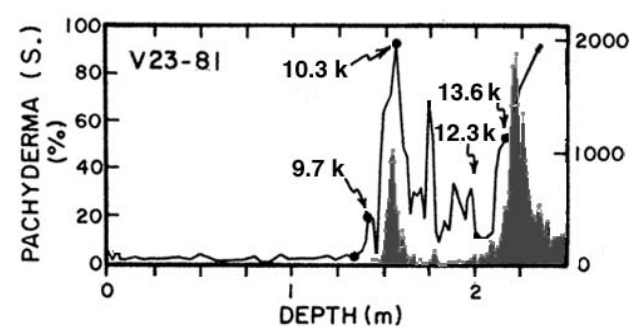

Figure 4: The positions of Heinrich events compared to climatic boundaries. Red curve plots the lithic abundance data provided courtesy of G. Bond showing Heinrich events $\mathrm{HO}$ and $\mathrm{H} 1$. Black curve plots the foraminifera ratio climate profile for core V23-81 (from Broecker et al. [63]). Radiocarbon dates are indicated by arrows.

\section{Box 1}

Timescale Adopted for Core V23-81

A timescale for dating the Heinrich events in core V23-81 is developed by correlating the climatic boundaries of this profile with corresponding climatic boundaries dated using the Cariaco chronology (Table 1). Dates for intervening depths have been interpolated. For depths, greater than 2.1 meters, the chronology is based on radiocarbon dates for core V23-81 published by Vogelsang et al. [64] and Sarnthein, which have been converted to calendar dates by using the radiocarbon conversions from INTCAL 09. The adopted time-depth model, displayed in Figure 5, gives a date of around 15.8 kyrs BP for the peak of event H1. Other researchers (e.g., Broecker et al. $[65,66])$ have dated the $\mathrm{H} 1$ event as peaking 16.8 to 17 kyrs $\mathrm{BP}$, hence over one thousand years earlier. The radiocarbon dates of Vogelsang et al. [64] in the depth range 2.1-2.4 m, which lie off the trend line, are here judged to be approximately 1200 years too old due to the influx of old carbon during the $\mathrm{H} 1$ meltwater discharge event. Similarly, radiocarbon dates in the depth range of 3.8-4.0 m are judged to be 1000-2000 years too old due to old carbon influx associated with the $\mathrm{H} 3$ meltwater discharge event.

Heinrich [62] proposed that the bedrock material making up these layers had been conveyed by armadas of icebergs launched from the edge of the ice sheet. He suggested that, during their journey out to sea,

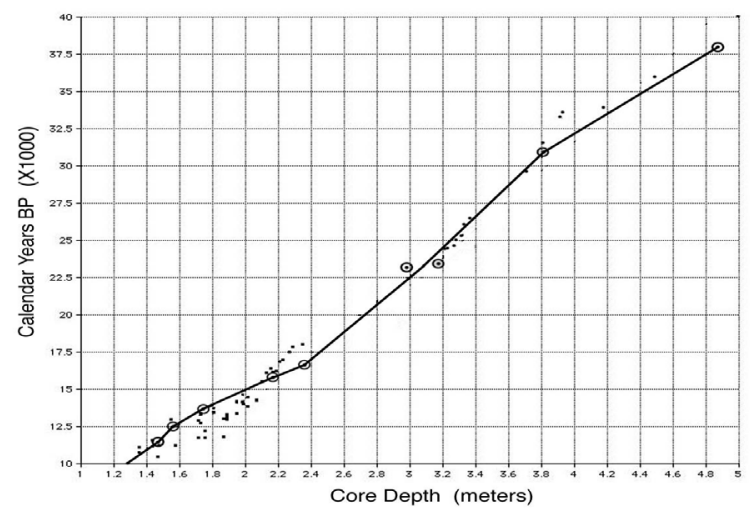

Figure 5: Time depth relationship adopted for core V23-81. Data points indicate radiocarbon dates of Vogelsand and Sarnthein converted to calendar dates. Conversion used the Cariaco Basin chronology for dates 10-12.55 k ${ }^{14} \mathrm{C}$ years BP and the INTCAL 09 chronology for dates $12.55-37 \mathrm{k}{ }^{14} \mathrm{C}$ years BP. For depths, greater than 4.495 meters a sedimentation rate of $101 \mathrm{yrs} / \mathrm{cm}$ was assumed. Circled points indicate dates adopted through climatic boundary correlations. 


\begin{tabular}{|c|c|c|}
\hline Depth (cm) & Years BP & Climatic zone \\
\hline 148 & 11,550 & Holocene begins \\
\hline 164 & 12,950 & Younger Dryas begins \\
\hline 175 & 13,250 & Intra-Alleröd cold peak max \\
\hline 200 & 14,130 & Older Dryas begins \\
\hline 210 & 14,700 & Bölling begins \\
\hline
\end{tabular}

Table 1: Dating Core V23-81 (150-210 cm) using Climatic Boundaries

the icebergs gradually melted and progressively released their trapped sediment. One problem with this theory, however, is that Heinrich layers begin with a sharp boundary suggesting that they were deposited far more suddenly and catastrophically than can be explained by rapid increases in iceberg population. X-ray studies carried out by Manighetti et al. [67] show that the bottom-most layer he examined had been deposited so abruptly that it had compressed the ocean bottom fluff layer, the thready surface zone produced by burrowing animals. Normally, this surface fluff layer migrates upward as sediment gradually accumulates. But in this case deposition was so sudden that the layer had no time to migrate. Instead, it became packed and preserved beneath the Heinrich layer as would have occurred if large amounts of sediment were dumped in a matter of hours. Strata consisting primarily of lithic grains and nearly devoid of foraminifera are found within Heinrich layers. The almost total absence of foraminifera in these strata indicates that they were necessarily deposited very rapidly.

It is proposed here that Heinrich layers were instead formed by the action of glacier waves. A sudden climatic warming, possibly triggered by the occurrence of one or more extreme solar events that caused meltwater to pond in great quantities on the ice sheet surface, would have been able to generate one or more glacier waves. These mega avalanches advancing at speeds of hundreds of kilometers per hour and passing in a matter of minutes would have been able to affect the rapid deposition indicated in these layers.

Johnson and Lauritzen [68] have proposed a similar mechanism for Heinrich layers in which repetitive jökulhlaups would have issued from a Hudson Bay lake upon repeated failure of an ice dam at the mouth of the Hudson Straight producing major fresh water pulses into the North Atlantic. The principal difference is that the JohnsonLauritzen mechanism proposes meltwater floods that issue from reservoirs situated either beneath or adjacent to the ice sheet and involving a single dam failure event. Whereas, according to the glacier wave concept proposed here, meltwater would originate from the upper surface of the ice sheet and produce a high volume, high kinetic energy meltwater wave that grows in size as it descends the ice sheet.

Ocean core studies show that foraminifera population dropped markedly during the period when Heinrich layers were being formed, with arctic species being the only one's present [69]. Rather than indicating a period of cold atmospheric climate, this could instead indicate that cold glacial meltwater was entering the oceans at the time of deposition. This is supported by isotopic studies, which show conspicuous decreases in planktonic $\delta^{18} \mathrm{O}$ ratio in these strata, indicating colder water temperatures and lower surface salinity.

Thinking that Heinrich events took place during periods of colder climate, researchers were originally led to assume that climatic cooling had caused the ice sheets to advance and that this in turn increased the rate of ice calving and hence the rate of iceberg rafting of continental soil to produce the observed Heinrich layers. But it is not clear how ice sheet advances or cooler climate would result in a dramatic increase in ice calving. One theory suggests a mechanical effect in which the ice sheet over the Hudson Bay, having reached a critical thickness and weight, sloughed down the Hudson Strait into the ocean. However, Heinrich layers were being produced by sediment transported in a synchronized fashion via geographically separated outflow channels. For example, there is evidence that some detritus in Heinrich layers is of Icelandic origin hence involving more easterly portions of the ice sheet. Consequently, to explain the sediment transported from the other locations similar ice surges would be needed for these other ice sheet locations. The ice sheet advance theory, however, has difficulty explaining such synchronization since advancing ice sheets would not be expected to necessarily calve ice at the same time. The climatically triggered glacier wave mechanism, on the other hand, accounts for why material was entering from various locations in a coordinated fashion. Some groups advocating the ice berg theory, such as Hulbe CL et al. [70], have instead considered climatic warming as being the trigger of these events. Their mechanism, like that of Heinrich, involves the release of ice berg armadas, although produced during a period of warming and ice melting rather than during a period of cold climate and ice sheet expansion.

Core V23-81, whose Heinrich layer record is displayed in Figures 3 and 4 was taken from a location that would have been about 700 kilometers west of the edge of the European ice sheet and about 1500 kilometers south of the edge of the Greenland Ice Sheet. Core DSDP 609, which also registers Heinrich layers, was taken from an even more remote location that formerly was situated about 1500 kilometers west of the edge of the European ice sheet and about 2000 kilometers south of the Greenland Ice Sheet. Heinrich layers have even been found off the coast of Portugal, at a distance of $3000 \mathrm{~km}$. Glacier waves would have been able to transport continental soil debris such great distances into the ocean since a sea ice shelf is believed to have bordered the ice sheet at those times. The divide between the Labrador Ice Sheet and the Keewatin Ice Sheet would have funneled glacier waves southward allowing them to pick up detritus from this valley and transport it southward over the bordering ice shelf. If comparable to the Ross Sea ice shelf, the North Atlantic ice shelf could have had a thickness of several hundred meters which would have made it strong enough to convey the brief passage of a glacier wave. If its southern margin were to consist of closely packed icebergs, this too could have had sufficient integrity to support a transient glacier wave. The reason why mid ocean Heinrich layers are not observed to occur in the midst of a prolonged interstadial or warm interval is that the ice shelf by that time would have melted away causing glacier waves to drop their debris much closer to shore.

The continental detritus data plotted in Figure 6 is taken from Bond et al. [71] and as with Figure 3, it uses the time-depth chronology presented in Table 1. The data are compared with the GISP2 Summit, Greenland ice core climate profile. Some Heinrich layers are found to correlate with periods of transition from cold to warm climate, as seen for Heinrich events $\mathrm{H} 0, \mathrm{H} 1$, and $\mathrm{H} 2$. On the assumption that the detritus was deposited suddenly, the sedimentation rate would have been abnormally high during a glacier wave passage. This implies that some layers would actually be more compressed in time than is evident in the plot shown in Figure 3. Nevertheless, it is also possible that a consecutive series of glacier waves could have blended to form a timeextended Heinrich layer. In fact, there is evidence of stratification being present within the Heinrich layers, suggesting that the material was not deposited by a single event, but by clusters of events. To explain these sharp boundaries and successive stratified layers a sudden depositional mechanism is needed, one capable of recurring at spaced intervals. Recurring glacier waves fit this requirement. The rapid deposition of 


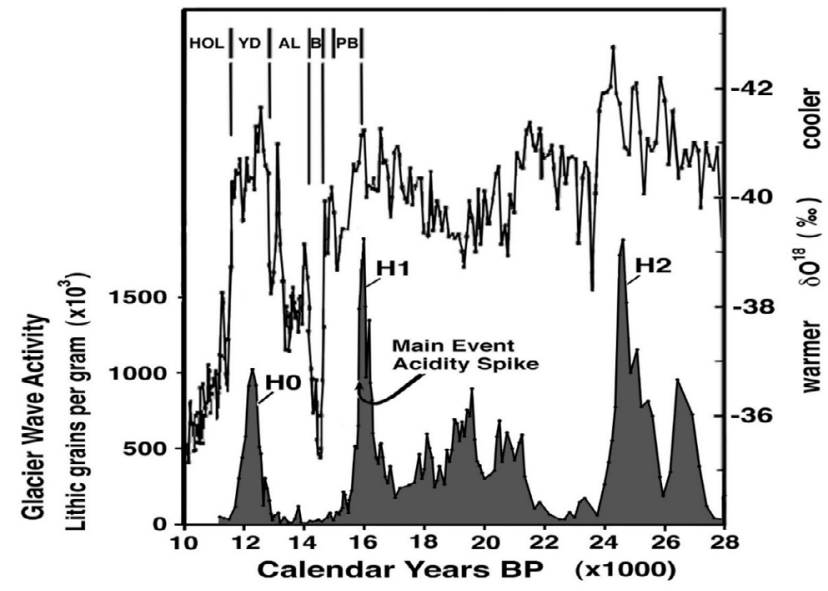

Figure 6: Dating of Heinrich layers compared with major climatic transitions. Upper profile: oxygen isotope climatic profile from the GISP2 Summit, Greenland ice core (lower values indicate warmer climate). Lower profile: Lithic grain abundance in sediments from North Atlantic core V23-81 $\left(54.5^{\circ} \mathrm{N}, 17.5^{\circ}\right.$ W); data courtesy of G. Bond. The timescale used for this core is described in the text box. Peaks designated as $\mathrm{H} 0, \mathrm{H} 1$, and $\mathrm{H} 2$ indicate Heinrich layers. Abbreviations designate the following climatic boundaries at the end of the ice age: Pre-Bölling Interstadial (PB), Bölling (B), Alleröd (AL), Younger Dryas (YD), and Holocene (Hol).

the detritus during any given event would explain the low prevalence of foraminifera within them.

As the ice shelf melted and broke up into an armada of ice bergs, any debris deposited on their surfaces by the glacier wave would have eventually been deposited on the ocean floor as the ice bergs melted. So, ice bergs could also have played a role in accounting for the delayed deposition of some of the debris.

Correlations of Heinrich events to oxygen isotope climate profile will tend to unintentionally show that a cold climate prevailed at the onset of a Heinrich event since isotope profiles have an inherent time lag in registering climatic changes causing their isotopic ratio to respond slowly to any abrupt warming. Heinrich layer $\mathrm{H} 1$ is of particular interest since the core chronology adopted here shows that it peaks near the beginning of the Pre-Bölling interstadial (15.8 kyrs $\mathrm{BP})$, the warming trend that began the deglaciation, which ended the ice age. This warming was global in extent since in Chile, mountain glaciers were rapidly retreating at this time [72]. Also, the Alerce, Chile climatic profile and Byrd Station, Antarctica ice core show that a major deglacial warming trend began at this time synchronous with the northern hemisphere warming [73] (Figures 1 and 5). Naafs et al. [74] have studied Heinrich layers in the North Atlantic between $40^{\circ}$ and $50^{\circ} \mathrm{N}$ and have found evidence that they occur in those locations in conjunction with surface water warming.

The onset in H1 lithic grain deposition shown in Figure 6 also correlates with the time of the Main Event acidity peak found in Antarctic ice [72] and which has been interpreted to indicate a period of increased cosmic dust influx into the solar system $[38,75]$. As mentioned earlier, a dusty solar environment could have been the cause of the elevated solar activity that appears to have prevailed at that time. A smaller Heinrich event labeled as $\mathrm{H} 0$ is seen to have an apparent culmination around $12.1 \mathrm{kyrs}$ BP. It correlates with a Younger Dryas interstadial warming evident in the Byrd Station, Antarctica and Summit, Greenland ice core climate profiles. A moderate rise in lithic grain deposition occurs at the beginning of this event around $12.7 \mathrm{kyrs}$ BP. This coincides with a major D/O warming seen in the Greenland ice core record (Figure 2). An increase in the radiocarbon excess seen around this date in the Floating Late Glacial Pine dendrochronology record [76] may indicate the occurrence of a super SPE.

The observation that Heinrich events coincide with the onset of climatic warming is even more dramatically illustrated in Figure 7, which correlates the timing of Heinrich events in core V23-81 with shifts in the GISP2 ice core ${ }^{15} \mathrm{~N} /{ }^{14} \mathrm{~N}$ isotope ratio [77] higher ${ }^{15} \mathrm{~N} /{ }^{14} \mathrm{~N}$ values indicating warmer temperatures. As is seen, the correspondence to the Heinrich event peaks is quite striking. The slight deviation for Heinrich event $\mathrm{H} 1$ may be attributed to inaccuracies in estimating the core's sedimentation rate for this period. In particular, considering that core sedimentation rate increases during Heinrich events due to the deposition of wave transported debris, peak $\mathrm{H} 1$ would span a shorter period of time than is indicated here and its onset would likely move to the left with an onset of $\sim 16$ kyrs BP to bring it into coincidence with the warm interval indicated in the Greenland ice core isotope ratio

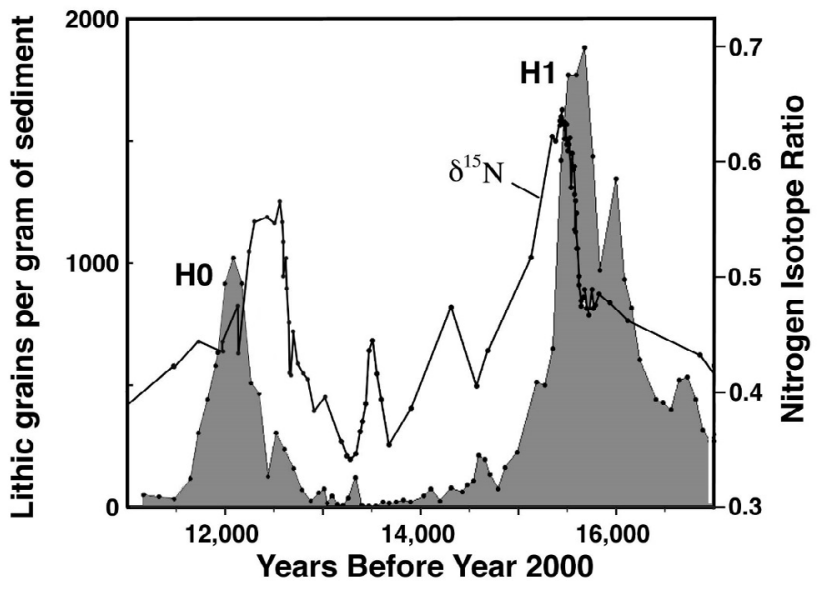

Figure 7: Isotopic nitrogen ratio in the GISP2 Greenland ice core (solid line) is compared to the timing of Heinrich Events in core V23-81 (shaded curve). Greater ${ }^{15} \mathrm{~N}$ ratio indicates warmer climate.

record.

Flower et al. [78] have measured $\mathrm{Mg} / \mathrm{Ca}$ ratios and $\delta^{18} \mathrm{O}$ ratios in foraminifera in Orca Basin core EN32-PC6 and find that seawater salinity declined during the interval 16.1 to $15.5 \mathrm{kyrs} \mathrm{BP}$, which preceded the more prominent salinity decline dating between 15.2-13.0 kyrs BP; see Figure 8 . They interpret both as an indication of an increased influx of glacial meltwater into the Gulf during this period. They note that the earlier meltwater influx event occurred during Heinrich event H1 which they have marked in their plot with a shaded band. The finding that $\mathrm{H} 1$ was associated with glacial melting and meltwater influx into the Gulf, in turn, supports the contention made earlier that Heinrich events are essentially powerful meltwater avalanches that discharge from the ice sheet during the onset of climatic warmings. The meltwater spike evident in the Younger Dryas portion of the $\mathrm{Mg} / \mathrm{Ca}$ profile, which dates at around 12.5 kyrs BP, may correlate with the detritus spike evident in the early part of Heinrich event $\mathrm{H} 0$ discussed earlier.

Over eight major Heinrich events have occurred over the course of the past 90,000 years and the number reaches almost 20 when more moderate events are included (Figure 3). In particular, the moderate detritus peak evident at $19 \mathrm{k}$ cal yrs BP in Figure 3 correlates with the 


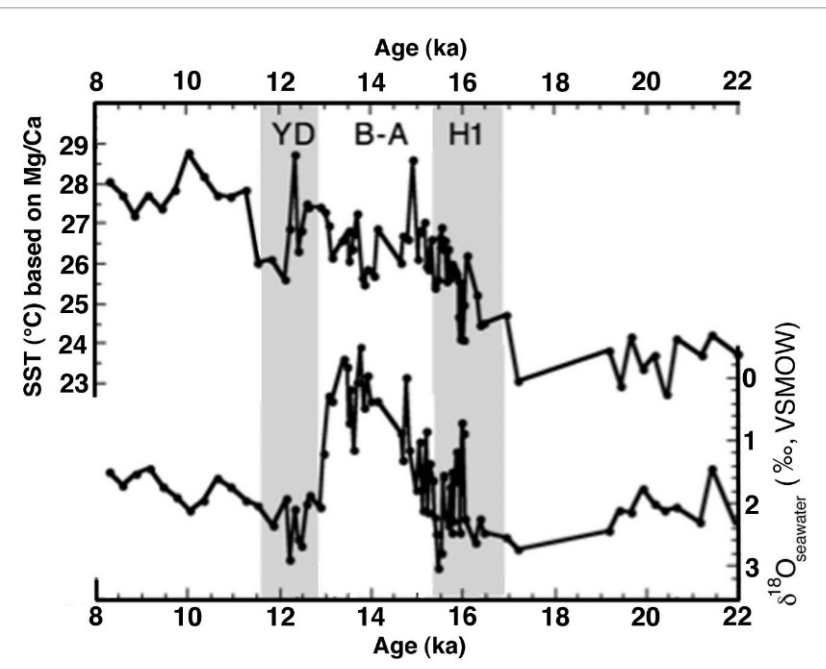

Figure 8: Upper profile: Orca Basin sea-surface temperatures based on $\mathrm{Mg} /$ Ca ratios from G. ruber in core EN32-PC6. Lower profile: Calculated $\delta 180$ seawater values based on paired $\delta 180$ values and $\mathrm{Mg} / \mathrm{Ca}$ ratios. From Flower et al. [78].

abrupt sea level rise event which Yokoyama et al. [20] report finding in Australia. Comparing the Heinrich event record with the Cariaco Basin radiocarbon excess record it is seen that times of major Heinrich events correlate with downturns in the radiocarbon excess. For example, declines in ${ }^{14} \mathrm{C}$ excess beginning around $39,000,32,000$, and 16,000 years BP correlate with the dates of Heinrich events $\mathrm{H} 5$ ( $39 \mathrm{k}$ cal yrs $\mathrm{BP}), \mathrm{H} 3$ (32 k cal yrs BP), and $\mathrm{H} 1$ (16 k cal yrs BP). These ${ }^{14} \mathrm{C}$ declines are easily explained if attributed to large amounts of radiocarbondepleted glacial meltwater entering the oceans and thereby lowering the ocean's ${ }^{14} \mathrm{C}$ concentration. Thus, these ${ }^{14} \mathrm{C}$ declines are further evidence that Heinrich events arise from glacial melting and meltwater discharge rather than from glacial growth.

The radiocarbon excess record for the Cariaco Basin sediment core shows that the period from 16,500 to 14,500 years BP experienced a $190 \pm 10$ per mil decline in the ${ }^{14} \mathrm{C}$ excess, equivalent to a $13.6 \%$ drop in the ${ }^{14} \mathrm{C} / \mathrm{C}$ ratio [79]. Broecker and Barker [80] suggest that this could be explained if radiocarbon-depleted meltwater had entered the ocean and mixed with surface water, but they could not locate a reasonable source. They consider the possibility that the water may have come from an isolated high-salinity ocean bottom reservoir that subsequently mixed with surface waters, but conclude that the size of the abyssal reservoir is insufficient to explain the decline. They acknowledge that alpine glaciers were rapidly retreating during this time, suggestive of a major climatic warming, but did not consider the possibility that the ${ }^{14} \mathrm{C}$ decline was due to radiocarbon-depleted meltwater entering the oceans from these receding glaciers and ice sheets.

Broecker and Barker [80] say that this period is referred to as the "Mystery Interval" since during this climatic warming unusually cold temperatures prevailed in the North Atlantic and western Mediterranean. But there is no mystery if one acknowledges that glacial meltwater entering the oceans at near $0^{\circ}$ centigrade would have kept sea surface temperatures low even during a climatic warming period. They mention that this ${ }^{14} \mathrm{C}$ decline falls close to the time of Heinrich event $\mathrm{H} 1$, but make no connection between the two events. One reason is that they date $\mathrm{H} 1$ as occurring about 17,500 years $\mathrm{BP}$ which would give it an end date prior to the beginning of the Mystery Interval.
However, when core V28-81 is dated as per the chronology adopted here, Heinrich event $\mathrm{H} 1$ is found to peak at 15.8 kyrs BP spanning the bulk of the Mystery Interval ${ }^{14} \mathrm{C}$ decline.

There is also evidence that Heinrich events $\mathrm{H} 5$ and $\mathrm{H} 3$ both correlate with times of elevated solar activity. H5 is found to follow: a) the Laschamp geomagnetic intensity minimum and geomagnetic reversal which extended from 40.8-42.3 $\mathrm{k}$ cal yrs BP [81], b) a very dramatic rise in ${ }^{14} \mathrm{C}$ excess from $42-40 \mathrm{k}$ cal yrs $\mathrm{BP}$ [79], and c) a very large ${ }^{10} \mathrm{Be}$ spike centred at $41 \mathrm{k}$ cal yrs $\mathrm{BP}$ [82], all indicating a period of extremely high solar and galactic cosmic ray activity. Also, Heinrich event $\mathrm{H} 3$ is found to correlate with the Mono Lake geomagnetic minimum and geomagnetic excursion which extended from $35-32 \mathrm{k}$ cal yrs BP [83].

\section{Conclusion}

Conditions were very different during the last ice age from what they are today. Ice sheets covered the Earth's high latitude regions and there are indications that the Sun was far more active. Abrupt climatic warmings occurred at recurrent intervals which were much more intense than anything seen in more recent times. As a consequence, there were times when supraglacial meltwater lakes covered the entire surfaces of the North American and European ice sheets to a far greater extent than is seen today in Greenland. Under such conditions, a glacier burst occurring somewhere on the ice sheet surface could trigger the successive emptying of other supraglacial lakes to form a self-amplifying high kinetic energy meltwater wave. Such glacier waves would have rapidly descended the ice sheet and, upon reaching its margin, would have been able to continue their journey creating catastrophic flooding of the surrounding land area. Calculations show that glacier waves reaching hundreds of miles per hour were a reasonable mechanism of meltwater transport at that time. Such waves could account for the upland permafrost silts in Alaska, for similar flood deposits in Siberia, for the many drumlin fields seen in North America, and for many of the lignite valley deposits seen in parts of Europe and North America. During times when an ice shelf existed off the coast of the Laurentide Ice Sheet, these waves could have traveled thousands of kilometers from the ice sheet margin releasing their debris to form the observed Heinrich layers in mid ocean sediments.

Upon crossing land areas that bordered the ice sheets, these immense flood waves would have posed a lethal hazard to land animals and to ice age man. These events could be the source of the many flood myths preserved by cultures all over the world [37].

\section{Acknowledgements}

I would like to thank the Starburst Foundation (starburstfound.org) for their help in funding the publication of this paper.

\section{References}

1. Dana JD (1880) Manual of Geology. American Book Co., New York.

2. Howorth HH (1887) The Mammoth and the Flood. Sampson Low, Marston, Searle, \& Rivington, London.

3. Baker VR (2009) Megafloods and global paleoenvironmental change on Mars and Earth. GSA Special 453: 25-36.

4. Kehew A Clayton L (1983) Late Wisconsin floods and development of the Souris-Pembina spillway system in Saskatchewan, North Dakota, and Manitoba. In Glacial Lake Agassiz pp: 187-210.

5. Péwé TL (1955) Origin of the upland silt near Fairbanks, Alaska. Bull. Geol Soc Am 67: 699-724.

6. Shaw J (1989) Drumlins, subglacial meltwater floods, and ocean responses 
Citation: LaViolette PA (2017) The Generation of Mega Glacial Meltwater Floods and Their Geologic Impact. Hydrol Current Res 8: 269. doi: 10.4172/2157-7587.1000269

\section{Geology 17: 853-856}

7. Shaw J, Kvill D, Rains B (1989) Drumlins and catastrophic subglacial floods. Sedimentary Geology 62: 177-202.

8. LaViolette PA (1983) Galactic Explosions, Cosmic Dust Invasions, and Climatic Change. Ph.D. dissertation, Portland State University, Portland, Oregon, p: 763.

9. Fitzpatrick AAW, Hubbard AL, Box JE, Quincey DJ, Van AD, et al. (2014) A decade (2002-2012) of supraglacial lake volume estimates across Russell Glacier, West Greenland. The Cryosphere 8: 107-121.

10. Koenig LS, Lampkin DJ, Montgomery LN, Hamilton SL, Turrin JB, et al. (2015) Wintertime storage of water in buried supraglacial lakes across the Greenland ice sheet. The Cryosphere 9: 1333-1342.

11. Smith LC, Chua VW, Yanga K, Gleasona CJ, Pitchera LH, et al. (2015) Efficient meltwater drainage through supraglacial streams and rivers on the southwest Greenland ice sheet. PNAS 112: 1001-1006.

12. Tedesco M, Fettweis X, Mote T, Wahr J, Alexander P, et al. (2013) Evidence and analysis of 2012 Greenland records from spaceborne observations, a regional climate model and reanalysis data. Cryosphere $7: 615-630$.

13. Fairbanks RG (1989) A 17,000 year glacio-eustatic sea level record: Influence of glacial melting rates on the Younger Dryas event and deep ocean circulation. Nature 342: 637-642.

14. Bard E, Hamelin B, Fairbanks RG, Zindler A (1990) Calibration of the ${ }^{14} \mathrm{C}$ timescale over the past 30,000 years using mass spectrometric $U$-Th ages from Barbados corals. Nature 345: 405-410.

15. Liu JP, Milliman JD (2004) Reconsidering melt-water pulses $1 \mathrm{~A}$ and 1B: global impacts of rapid sea-level rise. J Ocean University China 3: 183-190.

16. Clark PU, Mitrovica JX, Milne GA, Tamisiea ME (2002) Sea-level fingerprinting as a direct test for the source of global meltwater pulse 1A. Science 295: 24382441

17. Nerem RS, Chambers D, Choe C, Mitchum GT (2010) Estimating mean sea level change from the 32 TOPEX and Jason altimeter missions. Marine Geodesy 33: 435.

18. Emiliani C, Gartner S, Lidz B, Eldridge K, Elvey DE, et al. (1975) Paleoclimatological analysis of late quaternary cores from the northeastern Gulf of Mexico. Science 189: 1083-1088.

19. Abdul NA, Mortlock RA, Wright JD, Fairbanks RG (2016) Younger Dryas sea level and meltwater pulse 1B recorded in Barbados reef crest coral Acropora palmata. Paleoceanography 31: 330-344.

20. Yokoyama Y, Lambeck K, DeDeckker P, Johnston P, Fifield LK (2000) Timing of the Last Glacial Maximum from observed sea-level minima. Nature 406: 713 716.

21. Thorarinsson S (1953) Some new aspects of the Grimsvotn problem. J Glaciol 2: 267.

22. Ward RC (1978) Floods: A Geographical Perspective. New York: John Wiley \& Sons.

23. Mayer C, Lambrecht A, Hagg W, Helm A, Scharrer K (2008) Post-drainage ice dam response at Lake Merzbacher, Inylchek glacier, Kyrgyzstan. Geografiska Annaler a Physical Geography 90: 87-96.

24. Qiao L, Mayer C, Liu S (2015) Distribution and interannual variability of supraglacial lakes on debris-covered glaciers in the Khan Tengri-Tumor Mountains, Central Asia. Environ Res Lett 10: 014014.

25. Wagner G, Beer J, Masarik J, Muscheler R, Kubik PW, et al. (2001) Presence of the solar de Vries cycle ( 205 years) during the last ice age. Geophys Res Let 28: 303-306.

26. Clemens SC (2005) Millennial-band climate spectrum resolved and linked to centennial-scale solar cycles. Quat Sci Rev 24: 521-531.

27. Raspopov V, Dergachev V, Kozyreva O, Kolstrom T (2005) Climate response to de Vries solar cycles: evidence of Juniperus turkestanica tree rings in Central Asia. Mem SA It 76: 760-765.

28. Versteegh GJM (2005) Solar forcing of climate, 2: Evidence from the past Space Sci Rev 120: 243-286.

29. Braun H, Christl M, Rahmstorf S, Ganopolski A, Mangini A, et al. (2005) Possible solar origin of the 1470-year glacial climate cycle demonstrated in a coupled model. Nature 438: 208-211.
30. Velasco VM, Mendoza B (2008) Assessing the relationship between solar activity and some large 33 scale climatic phenomena. Adv Space Res 42: 866-878.

31. Braun $\mathrm{H}$ (2009) Strong indications for nonlinear dynamics during DansgaardOeschger events. Clim Past Discuss 5: 1751-1762.

32. Braun H, Kurths J (2010) Were Dansgaard-Oeschger events forced by the Sun? Eur Phy J Special Topics 191: 117-129.

33. Braun H, Ditlevsen P, Kurths J, Mudelsee M (2011) A two-parameter stochastic process for Dansgaard Oeschger events. Paleoceanography 26: PA3214.

34. Zook HA, Hartung JB, Storzer D (1977) Solar flare activity: Evidence for largescale changes in the past. Icarus $32: 106-126$.

35. Zook HA (1980) On lunar evidence for a possible large increase in solar flare activity approximately $2 \times 10^{4}$ years ago, In: The ancient sun: Fossil record in the earth, moon and meteorites. Proceed. Conf., Boulder, CO, October 16-19, 1979. New York and Oxford, Pergamon Press, 245-266.

36. Gold T (1969) Apollo II observations of a remarkable glazing phenomenon on the lunar surface. Science 165: 1345-49.

37. LaViolette PA (1997) Earth Under Fire. Rochester, VT: Bear \& Co.

38. LaViolette PA (2005) Solar cycle variations in ice acidity at the end of the last ice age. Planetary and Space Science 53: 385-393.

39. Narcisi B, Petit JR, Engrand C (2007) First discovery of meteoritic events in deep Antarctic (EPICA-Dome C) ice cores. Geophys Res Let 34: L15502.

40. LaViolette PA (2015) The episodic influx of tin-rich cosmic dust particles during the last ice age. Adv Space Res 56: 2402-2427.

41. Hoyle F, Lyttleton RA (1950) Variations in solar radiation and the cause of ice ages. J Glaciol 1: 453.

42. Bruns AV, Prokofiev VK, Severny AB (1970) On the contribution of solar activity to the ultraviolet spectrum of the Sun. In: Ultraviolet Stellar Spectra and Ground-based Observations, edited by Houziaux and Butler, pp: 256-259.

43. LaViolette PA (2011) Evidence for a solar flare cause of the Pleistocene mass extinction. Radiocarbon 53: 303-323.

44. Mörner NA (1978) Annual and Inter-Annual Magnetic Variations in Varved Clay. J Interdisci Cycle Res 9: 229-241.

45. Ising J (2001) Pollen analysis, chronology and palaeomagnetism of three Late Weichselian sites in southern Sweden. Thesis, Department of Quaternary Geology, Lund University.

46. Trenberth KE, Large WG, Olson JG (1989) The effective drag coefficient for evaluating wind stress over the oceans. J Climate 2: 1507-1516.

47. Baker VR (2009) Megafloods and global paleoenvironmental change on Mars and Earth. GSA 453: 25-36.

48. Weiss R, Fritz HM, Wünnemann K (2009) Hybrid modeling of the mega-tsunami runup in Lituya Bay after half a century. Geophy Res Lett 36: L09602.

49. Paik J, Shin, C (2015) Multiphase flow modeling of landslide induced impulse wave by VOF method. AGU Fall meeting abstract: NG23A-1764.

50. Péwé TL (1975) Quaternary Geology of Alaska. Geological Survey Professiona Paper 835.

51. Péwé TL (1975) Quaternary Stratigraphic Nomenclature in Unglaciated Central Alaska. Geological Survey Professional Paper 862.

52. Péwé TL, Journaux A, Stuckenrath R (1977) Radiocarbon dates and lateQuaternary stratigraphy from Mamontova Gora, unglaciated central Yakutia, Siberia, U.S.S.R. Quaternary Research 8: 51-63.

53. Taber S (1943) Perennially frozen ground in Alaska: Its origin and history Bulletin of the Geological Society of America 54: 1433-1548.

54. Eakin HM (1916) The Yukon-Koyukuk region, Alaska. U.S. Geological Survey 631. 55. Eakin HM (1918) The Cosna-Nowitna region, Alaska. U. S. Geological Survey 667.

56. Begossi R, Fávera JCD (2002) Catastrophic floods as a possible cause of organic accumulation giving rise to coal, Paraná Basin, Brazil. Intl J Coal Geol 52: 83-89.

57. Melentis JK (1963) Studies on the fossil vertebrates of Greece: 3. The osteology of the Pleistocene Proboscidians of the basin of Megalopolis in the Peloponnese (Greece). Annales 35 Géologiques des Pays Helléniques 14: 1-107. 
Citation: LaViolette PA (2017) The Generation of Mega Glacial Meltwater Floods and Their Geologic Impact. Hydrol Current Res 8: 269. doi: 10.4172/2157-7587.1000269

58. Melentis JK (1965) First find of Palaeoloxodon antiquus germanicus in the Young Pleistocene deposits of the basin of Megalopolis in the (Peloponnese). Internships Akadimias Athinon 40: 197-207.

59. Jack RL (1877) Glacial drift in the northeastern Carpathians, Quarterly Journal Geological Society of London 33: 673-681.

60. Lubbock J (1896) The scenery of Switzerland and the causes to which it is due Macmillan, New York.

61. Lyell C (1850) Principles of geology. D. Appleton, New York.

62. Heinrich $\mathrm{H}$ (1988) Origin and consequences of cyclic ice rafting in the northeast Atlantic Ocean during the past 130,000 years. Quaternary Research 29: 142-152.

63. Broecker WS, Andree M, Wolfli W, Oeschger H, Bonani G, et al. (1988) The chronology of the last deglaciation: Implications to the cause of the Younger Dryas event. Paleoceanography 3: 1-19.

64. Vogelsang E, Sarnthein M (2001) Age control of sediment core V23-81. Pangaea.

65. Broecker W (1994) Massive iceberg discharges as triggers for global climate change. Nature 372: 421-424.

66. Adams J, Maslin M, Thomas E (1999) Sudden climatic transitions during the Quaternary. Progress in Physical Geography 23: 1-36.

67. Manighetti B, McCave IN, Maslin M, Shackleton NJ (1995) Chronology for climate change: Developing age models for the biogeochemical ocean flux study cores. Paleoceanography 10: 513-525.

68. Johnson RG, Lauritzen SE (1995) Hudson Bay-Hudson Strait jökulhlaups and Heinrich events: A hypothesis. Palaeogeogr. Palaeoclimatol. Palaeoecol 117 123-137.

69. Bond G, Heinrich H, Broecker W, Labeyrie L, Mcmanus J, et al. (1992) Evidence for massive discharges of icebergs into the North Atlantic Ocean during the las glacial period. Nature 360: 245-249.

70. Hulbe CL, MacAyeal DR, Denton GH, Kleman J, Lowell TV (2004) Catastrophic ice shelf breakup as the source of Heinrich event icebergs. Paleoceanography 19: PA1004

71. Bond GC, Lotti R (1995) Iceberg discharges into the North Atlantic on millennial time scales during the last glaciation. Science 267: 1005-1010.
72. Lowell TV, Heusser CJ, Andersen BG, Moreno PI, Hauser A, et al. (1995) Interhemispheric correlation of late Pleistocene glacial events. Science 269: $541-1549$.

73. LaViolette PA (2005) Evidence of global warming at the Termination I boundary and its possible cosmic dust cause.

74. Naafs BDA, Hefter J, Stein R, Haug GH (2011) Evidence for surface water warming in the IRDbelt during Heinrich events. Interim Colloquium in Salamanca, Salamanca, Spain.

75. Hammer CU, Clausen HB, Langway CC Jr. (1997) 50,000 years of recorded global volcanism. Climatic Change 35: 1-15.

76. Hua Q, Barbetti M, Fink D, Kaiser KF, Friedrich M, et al. (2009) Atmospheric ${ }^{14} \mathrm{C}$ variations derived from tree rings during the early Younger Dryas. Quat Sci Rev 28: 2982-2990.

77. Severinghaus JP, Brook EJ (1999) Abrupt climate change at the end of the last glacial period inferred from trapped air in polar ice. Science 286: 930-934.

78. Flower BP, Hastings DW, Hill HW, Quinn TM (2004) Phasing of deglacial warming and Laurentide ice sheet meltwater in the Gulf of Mexico. Geology 32: $597-600$.

79. Hughen K, Lehman S, Southon J, Overpeck J, Marchal O et al. (2004) ${ }^{14} \mathrm{C}$ activity and global carbon cycle changes over the past 50,000 years. Science 303: 202-207.

80. Broecker W, Barker S (2007) A 190\%o drop in atmosphere's $\Delta^{14} \mathrm{C}$ during the "Mystery Interval (17.5 to $14.5 \mathrm{kyr}$ ). Earth and Planetary Science Letters 256 90-99.

81. Bourne MD, Mac Niocaill C, Thomas AL, Henderson GM (2013) High-resolution record of the Laschamp geomagnetic excursion at the Blake-Bahama outer ridge. Geophys J 195: 1519-1533.

82. Raisbeck G, Yiou F, Bourles D, Lorius C, Jouzel J, et al. (1987) Evidence for two intervals of enhanced ${ }^{10} \mathrm{Be}$ deposition in Antarctic ice during the last glacial period. Nature 326: 273-277.

83. Negrini RM, McCuan DT, Horton RA, Lopez JD, Cassata WS, et al. (2014) Nongeocentric axial dipole field behavior during the Mono Lake excursion. $\mathrm{J}$ Geophys Res 119: 2567-2581. 